\title{
Ecological Consciousness in William Wordsworth's Poetry
}

\author{
Xiuzhi Zhang \\ School of Foreign Studies, Xi'an University of Arts and Sciences, Xi'an 710065, China
}

\begin{abstract}
Keywords: William wordsworth; Ecological consciousness; Poetry; Harmonious; Respect.
\end{abstract}
\begin{abstract}
Wordsworth is one of the representatives of the romantic poetry. He tried to innovate new ways of writing in his poems and he regarded the poetry as a cure to man's depression. So this paper mainly focuses on William Wordsworth's ecological ideas and analyzes the relationship between man and nature, man's respect for nature and the esthetic value of nature and even the significance of his ideas represented in his poetry. The purpose is to arouse people's keen love for nature, to develop their ecological consciousness to protect the natural environment.
\end{abstract}

\section{Introduction}

William Wordsworth, one representative poet of the British romantic period and the leading voice of romantic poetry, was deemed to be one of the natural poets in British literature. When he was young, he saw the wondrous beauty of the Lake District and developed a special love for nature and he even visited places well-known for their scenic beauty in his spare time. Later he was involved in the French Revolution and his heart was inspired by the movement. It seemed that he could see a new light of freedom in the world. However, the conflict between France and Britain in 1793 made him disheartened and even the unplanned development of industrialization brought sufferings to people as well as to the environment. All these depressed him. Later in life, all his hope had fled, his illusion was gone and gradually he changed himself into a conservative, yet the influence of his early experience of the wild nature remained, and it made him put all his feelings and zest into his poetry.

Wordsworth's poems could be put into two groups: poems about nature and poems about human life. [1] But nature was something that gave him zest and peace. In his whole life, Wordsworth put all his deep love into nature, and believed the beauty of nature could thrill people. Therefore, nature was the everlasting theme in his poetry. In his opinion, nature could bring people peace, inspiration and psychological solace. So under his pen, the exquisite nature (the sky and clouds, the lakes and rivers, the flowers and grass, the meadows and woods, the rocks and cliffs, etc.)was alive and had spirit and it could heal people's mental disease. Wordsworth believed that nature could enrich people's heart, brought pleasure to them. Since last decade, Wordsworth has been generally recognized as one of the most important ecological poets.

\section{Ecological Consciousness.}

People's views of ecological consciousness are different. In general, it means the understanding of the law of the nature's variety. People's understanding to nature experienced the four stages. In the first stage, man's understanding to nature was superficial because of their thinking limitation and low capability. In their minds, nature was made by God and she should be holy. Therefore, they felt innocent and frightened before the wild and changeable nature, and even they became the slaves of nature. In the second stage, people complied with nature and they extracted what they needed from nature and changed nature slightly. Then in the third stage, they had confidence before nature and they believed that they could conquer nature with more efforts. Therefore, they thought they were the rules of nature, trying to change and control nature. After the industrialization, people kept on extracting things from nature and their desire was beyond the sustainable range of nature. They exploited nature madly, disturbing the balance between nature and man. So the relationship between the two of this period was to conquer and to be conquered. In the last stage, people realized they were closely linked with nature and they wanted to touch nature closely and coexist with nature. 
Wordsworth is seen as one of the most famous natural poets in England because of his deep love for the beautiful scenery, his experiences in nature and his concern for the pretty Lakes. He had made the Lake District his home for nearly his whole life. In his poetry, he was, either consciously or unconsciously, concerned with the good relationship between man and nature, his respect and love for nature and even the influence of nature on man. All his concerns represented in his poetry embodies his ecological consciousness.

\section{Wordsworth's Ecological Consciousness}

In Wordsworth's times, the Industrial Revolution made the rich wealthy and worsened the poor people's working and living conditions and Wordsworth experienced and observed the terrible conditions and showed pity for the poor. So he held a critical attitude to the ruling class. Later in life he went back to nature and advocated that man should return to nature.

Coexistence of Both Man and Nature. Marx once thought that man and nature is integrative and they interact each other. [2] This laid a foundation for the harmony between man and nature. Wordsworth was a great lover of nature and he was considered a poet who was keen on writing about natural things. He not only described about the beautiful nature, but also expressed the implied meaning of the relationship between man and nature.

From ecological views, we see that the most obvious feature in Wordsworth's poetry lies in his keen perception of beauty of nature and the close relationship between man and nature. In "I Wandered Lonely as a Cloud", the poet mainly describes his discovering a large patch of country daffodils moving in the light wind and its lasting effect on his quiet moments of reverie after he left irksome city life. It seemed that the cloud, vales, hills, daffodils and the poet himself formed an organic unity. Wordsworth put himself in nature and even he was immersed himself in nature. So he related: "I wandered lonely as a cloud/ That floats on high o'er vales and hills," [3] Here, the poet applies the image of a cloud to himself, moving aimlessly, which implied his integration with nature. His main purpose is to tell people that he is back to nature and the two can live harmoniously. The first three stanzas of this poem express that the poet feels alienated and lonely in the society and then when he returns to nature, he is infected by the beautiful scenery. In the fourth stanza, his memory comes back to the scene in his imagination. His happy mood appears to be recaptured. The poet depicts his wandering and sight of a large patch of daffodils by a lake, from which he gets tranquility and comforts. Nature provides beauty for him to appreciate. The flowers in nature are his friends, companions and partners, so nature helps him survive the worst period of his life. Here, we see nature and the poet himself are one unity and form a picture of the consistency of the two. Then the images of dancing flowers, the lake, the breeze and the waves, etc. reinforce the harmony between man and nature. So in Wordsworth's mind, man should go with the will of nature and live with nature harmoniously. Wordsworth illuminated a view of natural integrity and thought man was equal to nature [4] and the two can coexist. The poet sings of the harmony among things in nature and the harmony between nature and the poet himself. The two are unified.

Man's Respect and Worship of Nature. William Wordsworth got his inspiration from nature. He wrote lots of poems to express his genuine concern for the beautiful nature, such as "I Wandered Lonely as a Cloud," "Tintern Abbey," "An Evening Walk," etc. So "he is regarded as a "worship of nature"'. [5]

Wordsworth considered that man obtained material things from nature, so "man had to respect nature and worship her as he worships a God." [6] In "Tintern Abbey", the poet describes his revisit to the place and his present meditation and feelings. He begins with his revisit to the place that he has been to 5 years before and sees the vales, woods, cliffs, rocks, waters, etc.again. Even the place makes him recall the vagrant dwellers and hermits' cave. He feels that nature is really grand and makes man intoxicated. For "Nature never did betray//The heart that loved her." [3] This is the gift given to man by the miraculous nature. So nature gives man confidence and great joy and man learns to respect nature. The mountain, the wood, and their colors and forms, were then to the poet "An appetite: a feeling and a love" [7] Now everything in nature around him arose his passions, his desires and his excitement. Then he narrates his going back to nature and the lost joy and happy 
time in his youth returns. He praises the miraculous power of nature that can get rid of man's fickleness. When he is very disappointed at the industrial city life, he can have recourse to natural power and believes the mysterious nature can give him energy. Although his childhood joy is gone, he intoxicates himself in the beauty of natural world and it offers the whole beauty of man and nature, despite "the sad music of humanity" [3] and the cruel reality. Finally, from his sister, he recalls his past life and hopes that his sister can learn to respect nature, too. Here again, he mentions the wondrous power of nature and speaks out his feeling directly: "and that I, so long// A worshipper of Nature,..." [3] In spite of man's spiritual desolation, the distrust between man and man, Lawrence still hopes that the rupture between man and nature can be healed. This can be accomplished by changes of thinking about the relationship between man and nature. So nature should be held in high esteem by man. In"I Wandered Lonely as a Cloud," Wordsworth discovers a patch of country daffodils dancing lively in the light wind, enjoying the fresh air and then the poet's reverie returns. All these reveals the living nature. To Wordsworth, nature has breath, soul and life. Thus, the great nature in his poetry is loaded with life. He can communicate with nature. In Wordsworth's mind, man, as a partner of nature, should be a modest pupil before nature and respect it.

Esthetic Value of the Beauty of Nature. Wordsworth's esthetic value in his poetry lies in the influence of nature on man. He believed the wondrous nature could purify man's thought and enrich man's spirit. He considered nature as something to recuperate man's nature, remold man's soul, and even improve man's character. In Wordsworth's heart, nature can observe and guide man, cure man's mental disease and besides, nature can give comforts and energy to man.

"In vacant or in pensive mood,//They flash upon that inward eye// Which is the bliss of solitude;//And then my heart with pleasure fills,//And dances with the daffodils." [3] The poet expresses his feelings by describing the beautiful daffodils in nature. In his weariness, anxiety and frustration, he gets sensuous joy and calmness form these flowers. So the picturesque nature around him can make him forget the earthly cares and let him enjoy gentleness and calmness. We can see that the poet's imagination centers on the interplay between mind and nature and it is only after he has experienced and observed this scenery that he has the deep meditation of the interdependent relationship between nature and man [8] and the influence of this scenery on him.

In "Composed upon Westminster Bridge, September 3, 1802", the poet describes London city and the River Thames. He narrates the beauty and calmness of London City at sunrise. Standing on Westminster Bridge across the River Thames, he has a sense of reverence and rapture, and he believes he has never seen such a magical sighting before. In the poem, earth is personified as something that can touch the poet's heart. "This city now doth, like a garment, wear," [3] Here the city is personified as a person in a fine robe. It is alive and has life. Then ships, towers, domes, theaters, and temples, the fields and the sky form an exciting image of a primitive skyline in a clear, morning sky. Anyone who watches it will not miss the sight. At that time, London was blackened by smoke from the factories. But on this clear morning, the sky is so bright and the air is so fresh, smokeless that everything becomes shining and promising in the rising sun. Wordsworth uses his iconic images to form a very beautiful natural picture in our mind. Finally the poet describes the serene of the city, and there is nothing but peace in one's heart. So the beauty of nature brings tranquility to man and makes man be in good mood. This is the esthetic value represented in nature.

\section{The Significance of William Wordsworth's Ecological Consciousness}

Nowadays owing to the rapid development of the society and industrialization, people's thoughts have been greatly changed, and they pay more attention to the material things and their life becomes money-centered. They are out to get what they can from nature, and even they disturbs the balance of nature. Therefore, everywhere we can see the images of environmental destruction. The result is that people are badly hurt from these disasters. In order to meet with their own needs, they exploit nature madly and the interrelationship between man and nature is being destroyed. [9] Now people realize that they rely on nature and they should respect and protect nature. Wordsworth's poetry let them reconsider their attitude towards nature from the ecological perspective. 
From Wordsworth's poetry, we sense his ecological consciousness. Wordsworth was a lifelong advocate of the environmental protection because of his love and his respect for nature. He believed that "nature is the guider of man" [10] and that nature provides exaltation and comforts to man, so man should have a humble, correct attitude toward nature. He even recognized the importance of coexistence of man and nature. In Wordsworth's mind, natural beauty symbolized love and kindness, and it was the best cure for man's wounded heart. In addition, he had a keen understanding of nature's power and clearly understood that nature could bring man enjoyment, change man's nature, remold man's temperament and make the relationship between man and nature better. He observed the predicament of human existence and tried to arouse man's concern for nature in his poetry. To some extent, Wordsworth's ecological consciousness is an enlightenment to people nowadays.

\section{Conclusion}

Wordsworth is considered as an ecological poet. For all his life, he immersed himself in the beautiful landscape. Nature to him was something to console him and purify his soul. In his heart, nature has a positive influence on man's growth, spirit and health. So the good relationship between nature and man is beneficial for man's existence. Therefore, Wordsworth's ecological views in his poetry can arouse man's ecological ideas to protect nature.

\section{References}

[1] B.X. Zhang: Selected Readings In English And American Literatures (Foreign Language Teaching and Research Press, Beijing1998),p176.

[2] F.C. Wang: The Green Development and Marxist Principles on the Relationship Between Man and Nature, Economist,(2016),p.103. (in Chinese)

[3] W.R. Wang: History and Anthology of English Literature (Foreign Language Teaching and Research Press, Beijing2013),p.17-18.

[4] H.B. Zhu, X.M. LI: Cultural Values of Scenery in Wordsworth's Poetry, Language Planning, (2017),p.37. (in Chinese)

[5] G.Y. Dai: Examinee's Guide to Selected Readings in English and American Literatures (South China University of Technology Press, Guangdong2005),p.76

[6] B. Jonathan: Romantic Ecology ( New York, Routledge1991),p56.

[7] B.S. Liu: A Short History of English Literature, New Revised \& Enlarged Edition (He Nan people's Press, Zhengzhou2006),p.203.

[8] X.H. Wang: On Wordsworth's Ecological Views in His Poetry, Journal of Hubei University of Science and Technology, Vol.34 (2014) No.10, p.146. (in Chinese)

[9] Information on http://xueshu.baidu.com.

[10] Information on http://blog.sina.com.cn 